\title{
Phenotypic and Genotypic Characterization of Bradyrhizobia Nodulating the Leguminous Tree Acacia albida
}

\author{
NICOLAS DUPUY, ${ }^{1}$ ANNE WILLEMS, ${ }^{2}$ BRUNO POT, ${ }^{3}$, DIRK DEWETTINCK, ${ }^{3}$ ILSE VANDENBRUAENE ${ }^{3}$ \\ GLORIA MAESTROJUAN, ${ }^{3}$ BERNARD DREYFUS, ${ }^{1}$ KAREL KERSTERS, ${ }^{3}$ \\ MATTHEW DAVID COLLINS, ${ }^{2}$ AND MONIQUE GILLIS ${ }^{3 *}$
}

Laboratoire de Microbiologie des Sols, ORSTOM, Dakar, Senegal ; Department of Microbiology, Reading Laboratory, Institute of Food Research, Early Gate, Reading, RG $62 \mathrm{EF}$, United Kingdom ${ }^{2}$; and Laboratorium voor Microbiologie, Universiteit Gent, B-9000 Ghent, Belgium ${ }^{3}$

\begin{abstract}
Rhizobial isolates that were obtained from both surface and deep soil samples in the Sahelian and Sudano-Guinean areas of Senegal (West Africa) under Acacia albida trees were compared with representative strains of known rhizobial species and genera. Sodium dodecyl sulfate-polyacrylamide gel electrophoresis (SDS-PAGE) of proteins was used to determine the taxonomic positions of these organisms and the relationships between isolates obtained from the surface and isolates obtained from deep soil. Most of the isolates belonged to eight electrophoretic clusters containing representative strains of Bradyrhizobium japonicum, Bradyrhizobium elkanii, and Bradyrhizobium sp. Isolates were also characterized by the Biolog system, and the results were compared with the results obtained by SDS-PAGE of total proteins; the level of correlation was very low. DNA-rRNA hybridizations with 16S or $23 S$ rRNA from Bradyrhizobium japonicum LMG $6_{138}{ }^{\mathrm{T}}$ ( $\mathrm{T}=$ type strain) confirmed that most of the protein electrophoretic clusters belong in the Bradyrhizobium-Rhodopseudomonas rRNA complex. Sequencing of 16S rRNA genes showed that some of the $A$. albida-nodulating isolates belong to a separate lineage together with representatives of other protein electrophoretic clusters. Other isolates that belong to the same electrophoretic cluster as the type strain of Bradyrhizobium japonicum are considered members of the lineage represented by this type strain. The first lineage is as far removed from Bradyrhizobium japonicum as it is from the genus Afipia, Blastobacter denitrificans, and the genus Rhodopseudomonas. The possible relationship among electrophoretic group, geographic origin, and depth of isolation at a particular site is discussed.
\end{abstract}

Jordan $(15,16)$ divided the rhizobia into two genera, Rhizobium and Bradyrhizobium, containing fast-growing and slowly growing strains, respectively.

At one time the genus Rhizobium was divided into three species, Rhizobium leguminosarum (with Rhizobium leguminosarum bv. viciae, Rhizobium leguminosarum bv. phaseoli, and Rhizobium leguminosarum bv. trifolii), Rhizobium meliloti, and Rhizobium loti. In 1984 Scholla and Elkan (27) proposed a new species, Rhizobium fredii; later, Chen et al. (3) transferred this taxon on phenotypic grounds to the new genus Sinorhizobium and described a second species, Sinorhizobium xinjiangensis. Recently, however, on the basis of the results of partial $16 \mathrm{~S}$ rRNA sequence analyses Jarvis et al. (13) concluded that the name Sinorhizobium is a synonym of the name Rhizobium, that all fast-growing soybean-nodulating strains belong to a single species, Rhizobium fredii, and that additional studies are needed to confirm the status of Sinorhizobium xinjiangensis as a separate taxon. Since that time the following four new species have been proposed: Rhizobium galegae (21), Rhizobium huakuii (2), Rhizobium tropici (for the former Rhizobium leguminosarum bv. phaseoli type II) (22), and Rhizobium etli (for Rhizobium leguminosarum bv. phaseoli type I strains) (28).

According to Jordan (16), the genus Bradyrhizobium contained a single valid species, Bradyrhizobium japonicum. Within Bradyrhizobium japonicum different groups (some of which are considered members of separate species) have been recognized on the basis of the results of fatty acid analysis, resistance to different antibiotics, and DNA-DNA hybridiza-

\footnotetext{
* Corresponding author. Mailing address: Laboratorium voor Microbiologie, Universiteit Gent, K.-L. Ledeganckstraat, 35, B-9000
} Ghent, Belgium. Phone: 329264 5117. Fax: 3292645346. tion data $(9,16)$. On the basis of these results and DNA fingerprinting results a second species, Bradyrhizobium elkanii, was recently described for Bradyrhizobium japonicum DNA group II strains (19). In addition, there are many other bradyrhizobia without species epithets, and it has been suggested that these organisms should be designated Bradyrhizobium $\mathrm{sp}$., with the name of the appropriate host plant given in parentheses (15).

In 1988, Dreyfus et al. described the new genus Azorhizobium for Sesbania rostrata stem- and root-nodulating nitrogenfixing strains; currently a single Azorhizobium species, Azorhizobium caulinodans, is recognized (6). It has been proposed that there is a second, unnamed genomic species of this genus (26).

Graham et al. (9) have proposed minimal standards for the description of new genera and species. Polyphasic approaches, which rely on both phenotypic and genotypic criteria, are now having a major impact on the taxonomy of the rhizobia. The genera Rhizobium, Bradyrhizobium, and Azorhizobium represent different rRNA branches in the alpha subclass of the Proteobacteria (14, 29, 34-36). Internally, the genus Rhizobium is phylogenetically far more heterogeneous than the genus Bradyrhizobium (14, 34-36). Many more bacterial isolates from legume plants (representing diverse biotopes) should be included, and it is likely that more Rhizobium and Bradyrhizobium species will be described. Both of these genera are phylogenetically intertwined with other taxa (e.g., the genera Agrobacterium, Rhodopseudomonas, Nitrobacter, Blastobacter, and Afipia), indicating that a major revision of the classification of this group is needed.

To date, tropical rhizobia have been studied poorly, and only recently have comprehensive isolation and characterization 
TABLE 1. Isolates used

\begin{tabular}{|c|c|c|c|c|c|}
\hline Isolate $^{a}$ & $\begin{array}{l}\text { Host plant or source } \\
\text { of isolation }\end{array}$ & $\begin{array}{c}\text { Depth of } \\
\text { sampling }(\mathrm{m})^{b}\end{array}$ & Geographic origin & $\begin{array}{l}\text { PAGE } \\
\text { group }\end{array}$ & $\begin{array}{l}\text { Biolog } \\
\text { group }\end{array}$ \\
\hline \multicolumn{6}{|l|}{ New isolates } \\
\hline ORS 101 (= LMG 10664) & Acacia albida & & Senegal & 1 & IV \\
\hline ORS 103 (= LMG 10665) & Acacia albida & & Senegal & 1 & IV \\
\hline ORS 110 (= LMG 10666) & Acacia albida & 0.5 & Louga, North Senegal & 7 & II \\
\hline ORS 111 (= LMG 10667) & Acacia albida & 0.5 & Louga, North Senegal & 7 & II \\
\hline ORS 112 (= LMG 10668) & Acacia albida & 0.5 & Louga, North Senegal & 7 & II \\
\hline ORS $113(=$ LMG 10669) & Acacia albida & 0.5 & Louga, North Senegal & 7 & II \\
\hline ORS 114 (= LMG 10670) & Acacia albida & 0.5 & Louga, North Senegal & 24 & II \\
\hline ORS $115(=$ LMG 10671) & Acacia albida & 0.5 & Louga, North Senegal & 7 & II \\
\hline ORS $116(=$ LMG 10672) & Acacia albida & 0.5 & Louga, North Senegal & 7 & II \\
\hline ORS $117(=$ LMG 10673) & Acacia albida & 0.5 & Louga, North Senegal & 7 & II \\
\hline ORS 118 (= LMG 10674) & Acacia albida & 2.5 & Louga, North Senegal & 7 & II \\
\hline ORS 119 (= LMG 10675) & Acacia albida & 2.5 & Louga, North Senegal & 7 & II \\
\hline ORS 120 (= LMG 10676) & Acacia albida & 2.5 & Louga, North Senegal & 24 & II \\
\hline ORS 121 (= LMG 10677) & Acacia albida & 2.5 & Louga, North Senegal & 8 & II \\
\hline ORS $122(=$ LMG 10678) & Acacia albida & 5.0 & Louga, North Senegal & 8 & II \\
\hline ORS 123 (= LMG 10679) & Acacia albida & 5.0 & Louga, North Senegal & 8 & II \\
\hline ORS 124 (= LMG 10680) & Acacia albida & 17.5 & Louga, North Senegal & 7 & II \\
\hline ORS 125 (= LMG 10681) & Acacia albida & 17.5 & Louga, North Senegal & 7 & II \\
\hline ORS 126 (= LMG 10682) & Acacia albida & 17.5 & Louga, North Senegal & 7 & II \\
\hline ORS 127 (= LMG 10683) & Acacia albida & 17.5 & Louga, North Senegal & 3 & II \\
\hline ORS $128(=$ LMG 10684) & Acacia albida & 24.0 & Louga, North Senegal & 7 & II \\
\hline ORS 129 (= LMG 10685) & Acacia albida & 24.0 & Louga, North Senegal & 7 & II \\
\hline ORS $130(=$ LMG 10686) & Acacia albida & 27.5 & Louga, North Senegal & 8 & II \\
\hline ORS 131 (= LMG 10687) & Acacia albida & 28.5 & Louga, North Senegal & 7 & II \\
\hline ORS 132 (= LMG 10688) & Acacia albida & 28.5 & Louga, North Senegal & 7 & II \\
\hline ORS 133 (= LMG 10689) & Acacia albida & 30.0 & Louga, North Senegal & 7 & II \\
\hline ORS 134 (= LMG 10690) & Acacia albida & 30.0 & Louga, North Senegal & 8 & II \\
\hline ORS 135 (= LMG 10691) & Acacia albida & 32.0 & Louga, North Senegal & 3 & II \\
\hline ORS 136 (= LMG 10692) & Acacia albida & 32.0 & Louga, North Senegal & 7 & II \\
\hline ORS 137 (= LMG 10693) & Acacia albida & 33.5 & Louga, North Senegal & 7 & II \\
\hline ORS 138 (= LMG 10694) & Acacia albida & 33.5 & Louga, North Senegal & 7 & II \\
\hline ORS 139 (= LMG 10695) & Acacia albida & 34.0 & Louga, North Senegal & 7 & II \\
\hline ORS 140 (= LMG 10696) & Acacia albida & 34.0 & Louga, North Senegal & 7 & II \\
\hline ORS 141 (= LMG 10697) & Acacia albida & 0.5 & Diokoul, Central Senegal & 1 & I \\
\hline ORS 142 (= LMG 10698) & Acacia albida & 2.5 & Diokoul, Central Senegal & 4 & I \\
\hline ORS 143 (= LMG 10699) & Acacia albida & 4.0 & Diokoul, Central Senegal & 1 & I \\
\hline ORS $144(=$ LMG 10700) & Acacia albida & 11.5 & Diokoul, Central Senegal & 1 & I \\
\hline ORS 145 (= LMG 10701) & Acacia albida & 14.0 & Diokoul, Central Senegal & 1 & I \\
\hline ORS 146 (= LMG 10702) & Acacia albida & 14.0 & Diokoul, Central Senegal & 1 & I \\
\hline ORS 147 (= LMG 11359) & Acacia albida & 16.5 & Diokoul, Central Senegal & 1 & $\mathrm{ND}^{c}$ \\
\hline ORS 148 (= LMG 11943) & Acacia albida & 0.1 & Djinaki, South Senegal & 1 & $\operatorname{Sep}^{d}$ \\
\hline ORS 149 (= LMG 11944) & Acacia albida & 0.5 & Djinaki, South Senegal & 1 & I \\
\hline ORS 150 (= LMG 11945) & Acacia albida & 1.0 & Djinaki, South Senegal & Sep & I \\
\hline ORS 151 (= LMG 11946) & Acacia albida & 1.0 & Djinaki, South Senegal & 1 & III \\
\hline ORS 152 (= LMG 11947) & Acacia albida & 1.5 & Djinaki, South Senegal & 1 & I \\
\hline ORS 153 (= LMG 11948) & Acacia albida & 1.5 & Djinaki, South Senegal & 1 & III \\
\hline ORS $154(=$ LMG 11949) & Acacia albida & 2.0 & Djinaki, South Senegal & 1 & I \\
\hline ORS 155 (= LMG 11950) & Acacia albida & 3.0 & Djinaki, South Senegal & 1 & I \\
\hline ORS 156 (= LMG 11951) & Acacia albida & 4.0 & Djinaki, South Senegal & 1 & III \\
\hline ORS 158 (= LMG 11953) & Acacia albida & 5.0 & Djinaki, South Senegal & 1 & I \\
\hline ORS $159(=$ LMG 11954$)$ & Acacia albida & 5.0 & Djinaki, South Senegal & 1 & I \\
\hline ORS 160 (= LMG 10703) & Acacia albida & & Casamance, South Senegal & 3 & II \\
\hline ORS 161 (= LMG 10704) & Acacia albida & & Casamance, South Senegal & 21 & $I$ \\
\hline ORS $162(=$ LMG 10705) & Acacia albida & & Casamance, South Senegal & Sep & II \\
\hline ORS 163 (= LMG 10706) & Acacia albida & & Casamance, South Senegal & 3 & II \\
\hline ORS 164 (= LMG 10707) & Acacia albida & & Casamance, South Senegal & 4 & I \\
\hline ORS 165 (= LMG 10708) & Acacia albida & & Casamance, South Senegal & 1 & I \\
\hline ORS 166 (= LMG 10709) & Acacia albida & & Casamance, South Senegal & 3 & II \\
\hline ORS $167(=$ LMG 10710) & Acacia albida & & Casamance, South Senegal & 1 & I \\
\hline ORS $168(=$ LMG 10711) & Acacia albida & & Casamance, South Senegal & 3 & II \\
\hline ORS 169 (= LMG 10712) & Acacia albida & & Casamance, South Senegal & 1 & IV \\
\hline ORS 170 (= LMG 10713) & Acacia albida & & Casamance, South Senegal & 6 & III \\
\hline ORS 171 (= LMG 10714) & Acacia albida & & Casamance, South Senegal & 4 & I \\
\hline ORS 172 (= LMG 10715) & Acacia albida & & Casamance, South Senegal & 1 & I \\
\hline ORS 173 (= LMG 10716) & Acacia albida & & Casamance, South Senegal & 1 & I \\
\hline ORS 174 (= LMG 10717) & Acacia albida & & Casamance, South Senegal & 4 & V \\
\hline
\end{tabular}


TABLE 1-Continued

\begin{tabular}{|c|c|c|c|c|c|}
\hline Isolate $^{a}$ & $\begin{array}{l}\text { Host plant or source } \\
\text { of isolation }\end{array}$ & $\begin{array}{c}\text { Depth of } \\
\text { sampling }(\mathrm{m})^{b}\end{array}$ & Geographic origin & $\begin{array}{l}\text { PAGE } \\
\text { group }\end{array}$ & $\begin{array}{l}\text { Biolog } \\
\text { group }\end{array}$ \\
\hline ORS 175 (= LMG 10718) & Acacia albida & & Casamance, South Senegal & 6 & II \\
\hline ORS $176(=$ LMG 11955$)$ & Acacia albida & 0.1 & Kabrousse, South Senegal & 1 & I \\
\hline ORS 177 (= LMG 11956) & Acacia albida & 0.5 & Kabrousse, South Senegal & 1 & I \\
\hline ORS 178 (= LMG 11957) & Acacia albida & 1.0 & Kabrousse, South Senegal & 1 & I \\
\hline ORS $179(=$ LMG 11958) & Acacia albida & 1.5 & Kabrousse, South Senegal & ND & I \\
\hline ORS $180(=$ LMG 10719) & Acacia albida & & North Senegal & 1 & V \\
\hline ORS $181(=$ LMG 10720$)$ & Acacia albida & & North Senegal & 1 & I \\
\hline ORS 182 (= LMG 10721) & Acacia albida & & North Senegal & 11 & $\mathrm{~V}$ \\
\hline ORS 183 (= LMG 10722) & Acacia albida & & North Senegal & 11 & V \\
\hline ORS 184 (= LMG 10723) & Acacia albida & & North Senegal & Sep & V \\
\hline ORS $185(=$ LMG 10724$)$ & Acacia albida & & North Senegal & Sep & III \\
\hline ORS $186(=$ LMG 10725) & Acacia albida & & North Senegal & 1 & III \\
\hline ORS 187 (= LMG 10726) & Acacia albida & & North Senegal & 9 & III \\
\hline ORS $188(=$ LMG 10727$)$ & Acacia albida & & North Senegal & 1 & I \\
\hline ORS 189 (= LMG 10728) & Acacia albida & & North Senegal & Sep & V \\
\hline ORS 190 (= LMG 10729) & Acacia albida & & North Senegal & 1 & I \\
\hline ORS 191 (= LMG 10730) & Acacia albida & & North Senegal & 4 & Sep \\
\hline ORS $192(=$ LMG 10731) & Acacia albida & & North Senegal & 1 & I \\
\hline \multicolumn{6}{|l|}{ Reference strains } \\
\hline \multicolumn{6}{|l|}{ Bradyrhizobium japonicum strains } \\
\hline LMG $6138^{\mathrm{T}}\left(=\right.$ NZP $\left.5549^{\mathrm{T}}\right)$ & Glycine $\max (\mathrm{L}$.$) Merr.$ & & Japan & 1 & III \\
\hline LMG $6136(=$ NZP 5533) & Glycine $\max (\mathrm{L}$.$) Merr.$ & & United States & 3 & I \\
\hline LMG 8321 (= USDA 135) & Glycine $\max (\mathrm{L}$.$) Merr.$ & & United States & 3 & III \\
\hline \multicolumn{6}{|l|}{ Bradyrhizobium elkanii strains } \\
\hline LMG $6134^{\mathbf{T}}\left(=\right.$ USDA $\left.76^{\mathbf{T}}\right)$ & Glycine $\max$ (L.) Merr. & & & 6 & III \\
\hline LMG 6135 (= USDA 31) & Glycine $\max (\mathrm{L}$.$) Merr.$ & & United States & 6 & III \\
\hline \multicolumn{6}{|l|}{ Azorhizobium caulinodans strains } \\
\hline LMG $6465^{\mathrm{T}}\left(=\right.$ ORS $\left.571^{\mathrm{T}}\right)$ & Sesbania rostrata Brem. & & Senegal & 10 & ND \\
\hline LMG 11829 (= ORS 525) & Sesbania rostrata Brem. & & Senegal & 10 & ND \\
\hline \multicolumn{6}{|l|}{ Rhizobium tropici strains } \\
\hline LMG $9503^{\mathrm{T}}\left(=\right.$ CIAT $\left.899^{\mathrm{T}}\right)$ & Phaseolus vulgaris $\mathrm{L}$. & & & 13 & ND \\
\hline LMG $9517(=$ CFN 299) & Phaseolus vulgaris $\mathrm{L}$. & & & 13 & ND \\
\hline \multicolumn{6}{|l|}{ Rhizobium galegae strains } \\
\hline LMG $6214^{\mathrm{T}}\left(=\right.$ HAMBI $\left.540^{\mathrm{T}}\right)$ & Galega orientalis Lam. & & Finland & 14 & ND \\
\hline LMG $6215(=$ HAMBI 1147) & Galega orientalis Lam. & & Former USSR $^{e}$ & 14 & ND \\
\hline \multicolumn{6}{|l|}{$\begin{array}{l}\text { Rhizobium leguminosarum bv. phaseoli } \\
\text { strains }\end{array}$} \\
\hline LMG 8819t1 (= ATCC 14482) & Phaseolus sp. L. & & & 15 & ND \\
\hline LMG 8819t2 (= ATCC 14482) & Phaseolus sp. L. & & & 15 & ND \\
\hline $\begin{array}{l}\text { Rhizobium leguminosarum bv. viciae } \\
\text { LMG } 8817^{\mathrm{T}}\left(=\text { ATCC } 10004^{\mathrm{T}}\right)\end{array}$ & Pisum sativum $\mathrm{L}$. & & & 15 & ND \\
\hline \multicolumn{6}{|l|}{ Rhizobium loti strains } \\
\hline LMG 4284 (= USDA 3127) & Caragana arborescens & & United States & Sep & ND \\
\hline LMG $6123(=$ NZP 2037) & Lotus divaricatus & & New Zealand & $17^{2}$ & ND \\
\hline LMG $6125^{\mathrm{T}^{\mathrm{T}}}\left(=\mathrm{NZP} 2213^{\mathrm{T}}\right)$ & Lotus corniculatus & & New Zealand & Sep & ND \\
\hline \multicolumn{6}{|l|}{ Rhizobium fredii strains } \\
\hline LMG 8317 (= USDA 191) & Soil & & People's Republic of China & 20 & ND \\
\hline LMG $6217^{\mathrm{T}}\left(=\right.$ USDA $\left.205^{\mathrm{T}}\right)$ & Glycine $\max$ (L.) Merr. & & People's Republic of China & 20 & ND \\
\hline \multicolumn{6}{|l|}{ Rhizobium meliloti strains } \\
\hline LMG 6130 (= NZP 4009) & Medicago sativa $\mathrm{L}$. & & Australia & 22 & ND \\
\hline LMG $6133^{\mathrm{r}}\left(=\right.$ NZP $\left.4027^{\mathrm{T}}\right)$ & Medicago sativa $\mathrm{L}$. & & Australia & 22 & ND \\
\hline \multicolumn{6}{|c|}{$\begin{array}{l}\text { Representative strains from the study of } \\
\text { Moreira et al. }\end{array}$} \\
\hline \multicolumn{6}{|c|}{ Bradyrhizobium sp. strains } \\
\hline LMG 8888 (= USDA 300) & Acacia decurrens & & Brazil & 1 & ND \\
\hline INPA $60 \mathrm{~A}(=$ LMG 10045) & Machaerium madeirense & & Brazil & 1 & ND \\
\hline LMG 6129 (= NZP 2314) & Lotus pedunculatus & & Australia & 1 & ND \\
\hline LMG 6128 (= NZP 2309) & Lotus pedunculatus & & Australia & 1 & ND \\
\hline ORS 58 (= LMG 10663) & Dalbergia melanoxylon & & Senegal & 1 & I \\
\hline INPA 86A (= LMG 10053) & Swartzia sp. & & Brazil & 1 & ND \\
\hline BR $6817(=$ LMG 10010) & Pithecellobium sp. & & Brazil & 2 & ND \\
\hline FL $271(=$ LMG 10024) & Melanoxylon sp. & & Brazil & 2 & ND \\
\hline INPA 65B (= LMG 10046) & Inga sp. & & Brazil & 2 & ND \\
\hline INPA 9A $(=$ LMG 10029) & Derris sp. & & Brazil & 2 & ND \\
\hline INPA 254B (= LMG 10088) & Tachigalia paniculata & & Brazil & 2 & ND \\
\hline BR 6009 (= LMG 10001) & Lonchocarpus costatus & & Brazil & 3 & ND \\
\hline INPA 510B (= LMG 10109) & Derris negrensis & & Brazil & 3 & ND \\
\hline
\end{tabular}


TABLE 1-Continued

\begin{tabular}{|c|c|c|c|c|c|}
\hline Isolate $^{a}$ & $\begin{array}{l}\text { Host plant or source } \\
\text { of isolation }\end{array}$ & $\begin{array}{c}\text { Depth of } \\
\text { sampling }(\mathrm{m})^{b}\end{array}$ & Geographic origin & $\begin{array}{l}\text { PAGE } \\
\text { group }\end{array}$ & $\begin{array}{l}\text { Biolog } \\
\text { group }\end{array}$ \\
\hline BR 6011 (= LMG 9514) & Lonchocarpus costatus & & Brazil & 3 & ND \\
\hline BR 4407 (= LMG 9981) & Enterolobium ellipticum & & Brazil & 3 & ND \\
\hline BR 3621 (= LMG 9966) & Acacia mangium & & Brazil & 3 & ND \\
\hline BR $8205(=$ LMG 10014) & Poecilanthe parviflora & & Brazil & 3 & ND \\
\hline INPA 139A (= LMG 10064) & Entada polyphylla & & Brazil & 3 & ND \\
\hline INPA 147A (= LMG 10066) & Dimorphandra parviflora & & Brazil & 3 & ND \\
\hline BR 8402 (= LMG 10015) & Dalbergia nigra & & Brazil & 3 & ND \\
\hline INPA $14 \mathrm{~A}(=$ LMG 10032) & Clitoria racemosa & & Brazil & 5 & ND \\
\hline INPA $16 A(=$ LMG 10034) & Albizia lebbeck L. & & Brazil & 5 & ND \\
\hline INPA 104A (= LMG 10057) & Calliandra surinamensis & & Brazil & 5 & ND \\
\hline BR 3624 (= LMG 9968) & Acacia auriculaeformis & & Brazil & 6 & ND \\
\hline BR 6204 (= LMG 10004) & Samanea saman & & Brazil & 6 & ND \\
\hline BR 29 (= LMG 9520) & Unknown & & Brazil & 6 & ND \\
\hline BR 8406 (= LMG 10018) & Dalbergia nigra & & Brazil & 9 & ND \\
\hline INPA 147B (= LMG 10067) & Dimorphandra parviflora & & Brazil & Sep & ND \\
\hline BR $3606(=$ LMG 9959) & Acacia mollissima & & Brazil & 12 & ND \\
\hline INPA 66B (= LMG 10048) & Ormosia discolor & & Brazil & 12 & ND \\
\hline INPA $80 B(=$ LMG 10051) & Ormosia discolor & & Brazil & 12 & \\
\hline INPA $173 A(=$ LMG 10135) & Tachigalia paniculata & & Brazil & 12 & ND \\
\hline INPA 145A (= LMG 10065) & Dimorphandra parviflora & & Brazil & 19 & ND \\
\hline BR 4406 (= LMG 9980) & Enterolobium ellipticum & & Brazil & 19 & ND \\
\hline INPA 607A (= LMG 10122) & Derris negrensis & & Brazil & 19 & ND \\
\hline BR $5202(=$ LMG 9990) & Erythrina speciosa & & Brazil & 21 & ND \\
\hline INPA 589A (= LMG 10139) & Clathrotropis nitida & & Brazil & Sep & ND \\
\hline BR 5609 (= LMG 9997) & Albizia falcata & & Brazil & 24 & ND \\
\hline BR 5611 (= LMG 9998) & Albizia falcata & & Brazil & 25 & ND \\
\hline FL $281(=$ LMG 10026) & Abrus sp. & & Brazil & 25 & ND \\
\hline \multicolumn{6}{|l|}{ Rhizobium sp. strains } \\
\hline BR 814 (= LMG 9952) & Leucaena leucocephala & & Brazil & 16 & ND \\
\hline BR $6001(=$ LMG 10000) & Lonchocarpus sp. & & Brazil & 16 & ND \\
\hline BR 8803 (= LMG 10022) & Glicinidia sepium & & Brazil & 16 & ND \\
\hline INPA 78B (= LMG 10056) & Leucaena diversifolia & & Brazil & 17 & ND \\
\hline INPA 338A (= LMG 10093) & Leucaena diversifolia & & Brazil & 17 & ND \\
\hline INPA $129 \mathrm{~A}(=$ LMG 10061$)$ & Leucaena pulvurulenta & & Brazil & 17 & ND \\
\hline INPA $12 \mathrm{~A}(=$ LMG 10031) & Leucaena leucocephala & & Brazil & Sep & ND \\
\hline BR $6806(=$ LMG 10007) & Pithecellobium dulce & & Brazil & 18 & ND \\
\hline BR 819 (= LMG 9954) & Leucaena leucocephala & & Brazil & 18 & ND \\
\hline BR 5401 (= LMG 9993) & Sesbania marginata & & Brazil & Sep & ND \\
\hline BR 5404 (= LMG 9994) & Sesbania marginata & & Brazil & Sep & ND \\
\hline BR 8005 (= LMG 10012) & Clitoria racemosa & & Brazil & 23 & ND \\
\hline BR $8006(=$ LMG 10013) & Clitoria racemosa & & Brazil & 23 & ND \\
\hline
\end{tabular}

${ }^{a}$ ATCC, American Type Culture Collection, Rockville, Md.; BR and FL, strains from Centro Nacional de Pesquisa em Biologia do Solo, Seropedica 23851, Rio de Janeiro, Brazil; CFN, Centro de Investigacion sobre Fijacion de Nitrogeno, Universidad Nacional Autonoma de Mexico, Cuernavaca, Mexico; CIAT, Rhizobium Collection, Centro International de Agricultura Tropical, Cali, Colombia; HAMBI, Culture Collection of the Department of Microbiology, University of Helsinki, Helsinki, Finland; INPA, National Institute of Amazonia Research, Manaus, Brazil; LMG, Laboratorium voor Microbiologie Culture Collection, University of Ghent, Ghent, Belgium; NZP, Culture Collection of the Department for Scientific and Industrial Research Biochemistry Division, Palmerston, North, New Zealand; ORS, ORSTOM Collection, Institut Français de Recherche Scientifique pour le Développement en Coopération, Dakar, Senegal; USDA, U.S. Department of Agriculture, Beltsville, Md.

${ }^{b}$ If no value is given, the sample was obtained from the surface soil.

${ }^{c} \mathrm{ND}$, not determined.

${ }^{d}$ Sep, separate position on the dendrogram.

${ }^{e}$ See reference 23 .

programs begun $(4,7,23,30,37)$. A great deal of diversity with respect to cross-inoculation characteristics, as well as physiological and biochemical properties and protein profiles, has been observed. Several new groups of strains have been recognized, some of which have been characterized genotypically (4).

Acacia albida trees, which are native to Africa, are valued, especially as soil improvers by agroforesters and as a source of wood and aerial forage. Recently, Dupuy and Dreyfus (7) examined the distribution of rhizobial populations in deep soil under Acacia albida trees in the Sahelian and Sudano-Guinean areas of Senegal (West Africa). A total of 84 effective, typically slowly growing isolates [Bradyrhizobium sp. (Acacia albida)] were obtained from surface and phreatic soils (7). The purpose of this investigation was to taxonomically characterize these isolates by using both phenotypic (sodium dodecyl sulfate [SDS]-polyacrylamide gel electrophoresis [PAGE]) of wholecell protein extracts, Biolog tests) and genetic (DNA-rRNA hybridization, comparative sequencing of $16 \mathrm{~S}$ rRNA genes) approaches.

\section{MATERIALS AND METHODS}

Isolates. A total of 84 new Bradyrhizobium sp. (Acacia albida) strains were used in this study (Table 1). Originally, isolated from soil, these strains were enumerated by the plant 
infection most-probable-number technique as described previously (7). All of the isolates typically grew slowly (colonies appeared in 5 or 6 days) on yeast extract-mannitol (YM) medium (33) and thus were considered members of the genus Bradyrhizobium (7). Standard nomenclature, including the form Bradyrhizobium sp. (Acacia albida) as proposed by Jordan (16), was used for all strains that belonged to either protein electrophoretic clusters containing Bradyrhizobium reference strains or protein electrophoretic clusters which contained a representative strain belonging to the Bradyrhizobium rRNA cluster. All of the isolates were maintained in YM broth containing $20 \%$ (vol $/ \mathrm{vol}$ ) glycerol at $-80^{\circ} \mathrm{C}$. The other strains used were type strains and/or representatives of Rhizobium, Bradyrhizobium, and Azorhizobium species. Representative strains belonging to the protein electrophoretic clusters described by Moreira et al. (23) were also included.

Growth conditions. Strains were grown on YM agar at $28^{\circ} \mathrm{C}$ for 5 to 7 days. Purity was checked by repeatedly streaking single colonies on agar plates and examining the preparations by light microscopy.

SDS-PAGE and numerical analysis of the protein electrophoretic patterns. Strains were grown as described previously (23). Extracts of SDS-soluble proteins were prepared from whole cells as described previously (17). Proteins were separated by SDS-PAGE by using a slight modification (17) of the method described by Laemmli (20). A densitometric analysis, normalization and interpolation of the protein profile data, and a numerical analysis were performed by using the GelCompar 2.0 software package (31). The profiles were recorded and stored on a personal computer. The levels of similarity between pairs of traces were expressed by using the Pearson product moment correlation coefficient $(r)(24,25)$.

Biolog system. In the commercially available microtiter plate test (Biolog, Inc., Hayward, Calif.) oxidation of 95 different carbon sources is determined. The genus Bradyrhizobium is not included in the commercially available data base used for identification of gram-negative bacteria. Because of the low levels of activity of the bradyrhizobia, the procedure was adapted as follows. The strains were grown on plates containing TYB (TY in which MC.2 agar [Lab M] was replaced by Difco bacteriological agar) for 8 days at $28^{\circ} \mathrm{C}$. In order to obtain sufficient cell material, the cells were transferred to fresh TYB plates by using sterile swabs. From each second culture (which was incubated for 8 days at $28^{\circ} \mathrm{C}$ ), cells were harvested by rolling a sterile swab over the plate and resuspending the cells in sterile physiological saline $(0.85 \% \mathrm{NaCl})$ to an optical density at $590 \mathrm{~nm}$ of 0.260 to 0.300 . The resulting suspension was used to inoculate a Biolog microtiter plate $(150$ $\mu l$ per cupule). The plates were wrapped in Parafilm and were incubated for 5 days at $33^{\circ} \mathrm{C}$. The occurrence of any trace of purple was recorded manually before and after the purple precipitate was resuspended with a sterile wire. The results were compared with the results obtained with a control well containing no substrate. The result was recorded as positive or negative and was analyzed numerically by using $r$ values and an adaptation of the GelCompar computer program $(31,32)$.

DNA-rRNA hybridizations. Strains were grown on TY medium in Roux flasks for 5 days at $28^{\circ} \mathrm{C}$. The cells were harvested and washed in $0.01 \mathrm{M}$ phosphate buffer ( $\mathrm{pH} \mathrm{7)}$. DNA was extracted as described previously (14). $\left[{ }^{14} \mathrm{C}\right] \mathrm{rRNA}$ from Bradyrhizobium japonicum LMG $6138^{\mathrm{T}}$ (T = type strain) was obtained from members of our research group. A new ${ }^{3} \mathrm{H}$-labeled rRNA was prepared as described previously (14), except that ${ }^{3} \mathrm{H}$-labeled 5-orotate and ${ }^{3} \mathrm{H}$-labeled 2,8-adenine were added as precursors. DNA-rRNA hybridizations were carried out, and the temperature at which $50 \%$ of each hybrid was denatured $\left[T_{m(e)}\right]$ was determined as described previously (14).

Analysis of the 16S rRNA gene. The following strains were used to analyze the 16S rRNA gene: Bradyrhizobium sp. strains BR 6011, BR 29, BR 3621, BR 4406, and ORS 133. A 1,440-nucleotide fragment of the 16S rRNA gene (positions 21 to 1521; Escherichia coli numbering system [1]) was amplified and sequenced directly by using SEQUENASE version 2.0 (United States Biochemicals, Cleveland, Ohio) as described previously $(31,34)$. The sequences obtained, together with reference sequences obtained from the EMBL data library, were aligned by using the multiple-alignment programs PILEUP, PRETTY, and UGLY in the Genetics Computer Group sequence analysis package (version 7.01) (5) and a VAX computer. An unrooted phylogenetic tree was produced by using the DNADDIST and FITCH programs in the Phylogeny Inference Package (8), and bootstrap analysis was performed by using the SEQBOOT and CONSENSE programs in the same package.

Nucleotide sequence accession numbers. The sequences were deposited in the EMBL data library under accession numbers X70401 to X70405.

\section{RESULTS}

Comparative SDS-PAGE of whole-cell proteins. The protein patterns of all of the new Acacia albida-nodulating strains listed in Table 1 were scanned and analyzed numerically, together with the protein patterns of selected reference strains available in the data base of our research group. The resulting grouping scheme was checked by visualization and comparison of the digitized patterns. The reproducibility of the protein patterns was good; the $r$ values were 0.96 for replicate experiments performed with a single extract on the same gel, 0.93 for replicate experiments performed with a single extract on different gels, and 0.91 for replicate experiments performed with different extracts of one strain. The results are shown in a similarity dendrogram in Fig. 1. Above mean $r$ values of \pm 0.89 , 25 protein electrophoretic clusters (clusters 1 to 25 ) and 12 ungrouped strains were identified. Most of the Bradyrhizobium strains and the Acacia albida-nodulating isolates clustered at $r$ values greater than 0.85 in clusters 1 to 9 . Almost $91 \%$ of the new slowly growing strains that nodulated Acacia albida belonged to six gel electrophoretic groups (clusters 1, 3, 4, 6, 7, and 8 ); clusters 4,7 , and 8 contained only new isolates, while clusters 1, 3, and 6 also contained representative Bradyrhizobium strains. The type strain of the Bradyrhizobium type species, Bradyrhizobium japonicum LMG 6138, was a member of cluster 1 . A minority of the Acacia albida-nodulating strains belonged to smaller clusters (clusters 9, 11, 21, and 24), and five strains (ORS 184, ORS 162, ORS 150, ORS 189, and ORS 185) were found at separate positions. Figure 2 shows a computer-processed printout of the data for positions 0 to 350 in the digitized and normalized protein patterns of representatives of the different clusters.

In a previous investigation it was shown that 92 slowly growing strains isolated from diverse tropical leguminous plants in Brazil belonged to a single cluster that included Bradyrhizobium reference strains (23). This cluster was subdivided into five subclusters (subclusters $A$ through $E$ ), and representative strains of these subclusters were also included in this study. These organisms were members of clusters $1,2,3,5$, 6 , and 9. The compositions of our protein gel electrophoretic clusters are described below.

Cluster 1 contains the type strain of Bradyrhizobium japoni- 


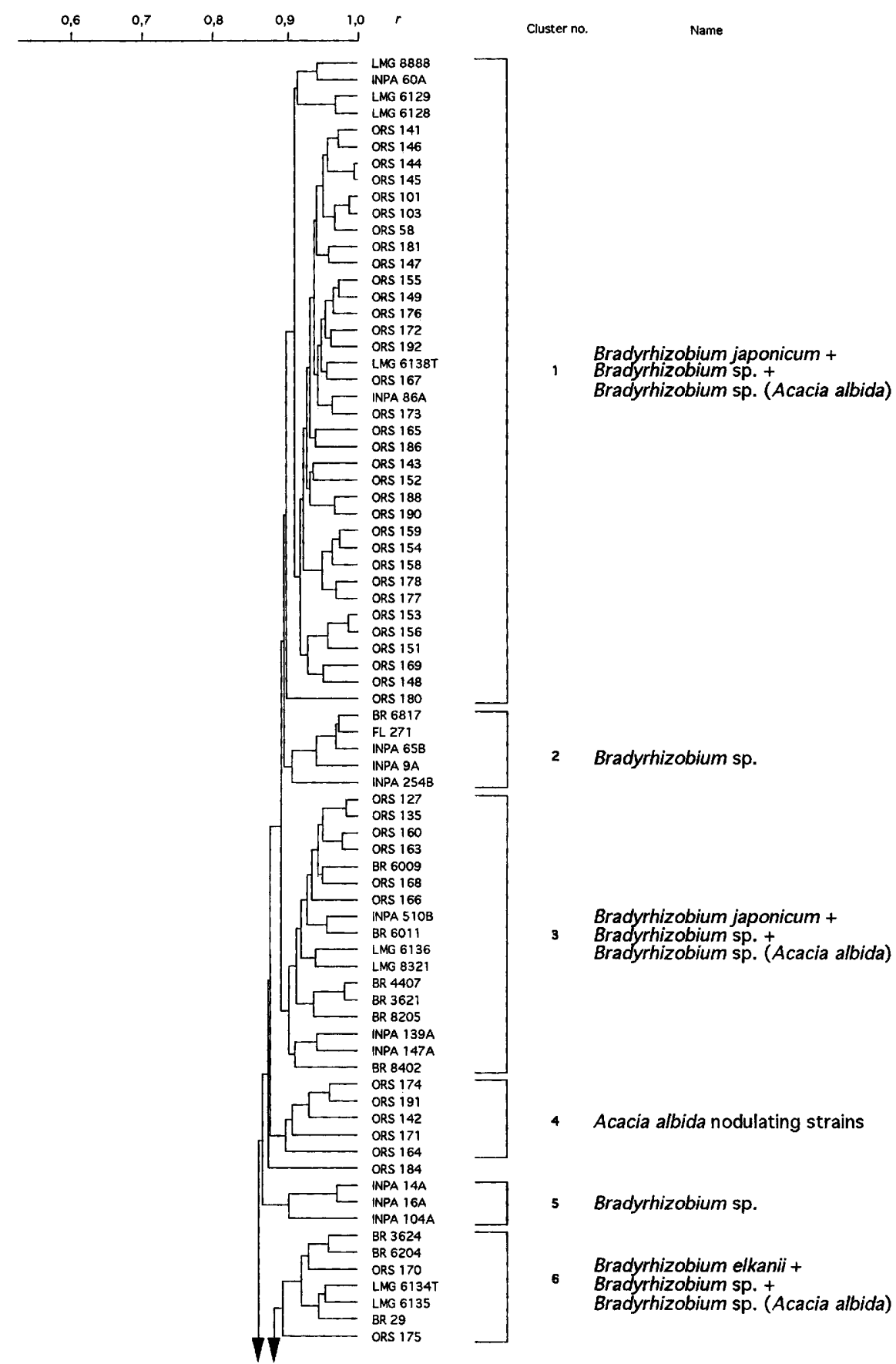

FIG. 1. Gel electrophoretic results presented as a dendrogram based on $r$ values, as calculated by the unweighted group method using average linkage.

cum (strain LMG 6138), representative strains belonging to Bradyrhizobium subcluster B (LMG 8888, INPA 60A, LMG 6129, LMG 6128, INPA 86A), strain ORS 58 isolated from Dalbergia melanoxylon, and 32 Acacia albida-nodulating isolates, including 6 of the 7 strains obtained from Diokoul, 10 of the 11 strains obtained from Djinaki, 5 strains isolated from various surface samples obtained from Sudano-Guinean (Casamance) soil, 3 of the 4 strains isolated from Kabrousse soil samples, and 6 of the 13 strains isolated from various Sahelian soil samples from North Senegal.

Clusters 2 and 5 contain only Brazilian strains representing part of Bradyrhizobium subcluster B and cluster 13, respectively (23).

Cluster 3 contains most of the Brazilian strains representing Bradyrhizobium subcluster A, two strains obtained from Louga, four strains obtained from Casamance surface soil, and Bradyrhizobium japonicum LMG 6136 and LMG 8321.

Cluster 4 contains only Acacia albida-nodulating isolates, including one strain obtained from Diokoul, three strains obtained from Sudano-Guinean surface soil, and one strain obtained from Sahelian surface soil.

Two strains obtained from Sudano-Guinean surface soil are 


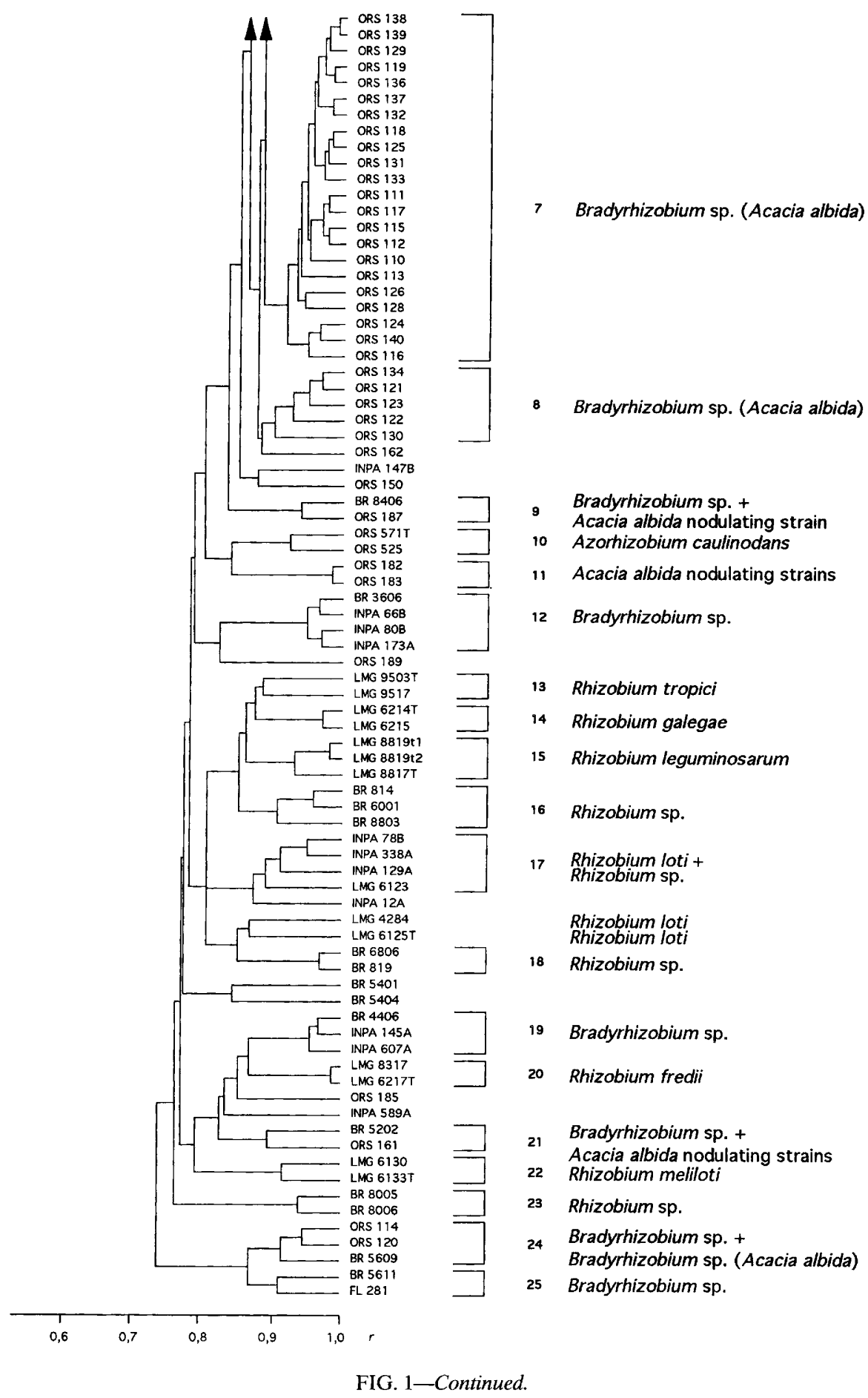

members of cluster 6 , together with four representative Bradyrhizobium subcluster E strains, including the type strain of Bradyrhizobium elkanii (LMG 6134) and strain BR 29 belonging to subcluster $\mathrm{C}$.

Clusters 7 and 8 contain only Acacia albida-nodulating isolates obtained from Louga.

Strain BR 8406 (isolated from Dalbergia nigra and belonging to Bradyrhizobium subcluster A) clustered with an isolate obtained from Sahelian surface soil (ORS 187) in cluster 9.
None of the new isolates belongs to Bradyrhizobium subclusters C and D of Moreira et al. (23); we found that representatives of these two Bradyrhizobium subclusters are members of clusters 12 and 19 , respectively.

Clusters 1 to 9 exhibited the highest levels of intercluster similarity. When we examined the clustering at $r$ values of less than 0.84 , we made several observations. (i) Some of the clusters correspond to known species belonging to the genera Rhizobium and Azorhizobium. Cluster 10 corresponds to Azo- 


\begin{tabular}{|c|c|c|}
\hline \multirow[t]{35}{*}{ Normalized protein pattern } & Strain no. & Cluster no. \\
\hline & ORS 144 & 1 \\
\hline & ORS 103 & 1 \\
\hline & ORS 178 & 1 \\
\hline & ORS 153 & 1 \\
\hline & LMG 6138 & 1 \\
\hline & INPA 2548 & 2 \\
\hline & ORS 135 & 3 \\
\hline & BR 6009 & 3 \\
\hline & ORS 174 & 4 \\
\hline & INPA 14A & 5 \\
\hline & ORS 170 & 6 \\
\hline & BR 6204 & 6 \\
\hline & ORS 133 & 7 \\
\hline & ORS 138 & 7 \\
\hline & ORS 134 & 8 \\
\hline & ORS 187 & 9 \\
\hline & ORS $571 T$ & 10 \\
\hline & ORS 182 & 11 \\
\hline & INPA $173 A$ & 12 \\
\hline & LMG 9503 & 13 \\
\hline & LMG 9517 & 13 \\
\hline & LMG 6214 & 14 \\
\hline & LMG 8817 & 15 \\
\hline & BR 8803 & 16 \\
\hline & LMG 6123 & 17 \\
\hline & LMG 6125 & separate \\
\hline & BR 6806 & 18 \\
\hline & INPA $145 \mathrm{~A}$ & 19 \\
\hline & LMG 6217 & 20 \\
\hline & ORS 161 & 21 \\
\hline & LMG 6133 & 22 \\
\hline & BR 8005 & 23 \\
\hline & ORS 114 & 24 \\
\hline & FL 281 & 25 \\
\hline
\end{tabular}

$\begin{array}{lllll}\text { FIG. 2. Computer-processed printout for position } 0 \text { (top of gel, } & \text { I }\end{array}$ right side of pattern) to position 350 (front of gel, left side of pattern) of the digitized and normalized protein patterns of representative strains belonging to the different SDS-PAGE clusters. MWM, molecular weight markers.

rhizobium caulinodans; cluster 13 strains $\mathrm{LMG} 9503^{\mathrm{T}}$ and LMG 9517 represent the two subgroups of Rhizobium tropici; cluster 14 corresponds to Rhizobium galegae; and cluster 15 corresponds to Rhizobium leguminosarum. Cluster 17 corresponds to cluster 2 of Moreira et al. (23) and contains a named Rhizobium loti strain (LMG 6123). However, two other Rhizobium loti strains, including the type strain, occupy a somewhat separate position. Additional taxonomic studies of cluster 17 and related strains will be described elsewhere (4). Cluster 20 corresponds to Rhizobium fredii, and cluster 22 corresponds to Rhizobium meliloti. (ii) Some clusters correspond to unnamed clusters described by Moreira et al. (23) (clusters 16, 18, 23, and 25). (iii) Two clusters (clusters 12 and 19) contain representative Bradyrhizobium strains. (iv) Two Acacia albida-nodulating strains isolated from Sahelian surface soil, ORS 182 and ORS 183, are members of cluster 11. Strain ORS 161, an isolate that was obtained from Casamance soil, is related to strain BR 5202 (cluster 21), which was isolated from Erythrina speciosa. The two isolates obtained from Louga soil (ORS 114 and ORS 120) belong to cluster 24, which corresponds to cluster 16 of Moreira et al. (23); strain BR 5609 (isolated from Albizia falcata) is a representative of this cluster.

Biolog system. Table 2 shows the results of the 95 substrate oxidation tests which we performed. The results of the cluster analysis are shown in Fig. 3. At an $r$ value of 0.82 three large clusters (clusters I to III) and two smaller clusters (clusters IV and V) were identified; two strains (ORS 148 and ORS 191) were not grouped. Phenotypic cluster I contains all but six of the Acacia albida-nodulating isolates belonging to PAGE cluster 1, three of the five strains belonging to PAGE cluster 4, and one strain belonging to PAGE cluster 3 (LMG 6136). Phenotypic cluster II contains all of the Acacia albida-nodulating strains belonging to PAGE clusters $3,7,8$, and 24 , a single strain belonging to PAGE cluster 6 (ORS 175), and ungrouped isolate ORS 162. Phenotypic cluster III contains five PAGE cluster 1 strains, Bradyrhizobium japonicum LMG 8321 , two reference strains belonging to PAGE cluster 6 , one Acacia albida-nodulating strain belonging to PAGE cluster 9, and an ungrouped strain. Phenotypic cluster IV contains three strains belonging to PAGE cluster 1 . Cluster V consists of both strains belonging to PAGE cluster 11, one PAGE cluster 1 strain, one PAGE cluster 4 strain, and two ungrouped strains. The reproducibility of the substrate oxidation tests was good; for strains ORS 132 and ORS 134, the results of replicate experiments performed with different concentrations of cell inoculum (designated $\mathrm{x}$ and $\mathrm{y}$ ) had an $r$ value of 0.97 . For strain ORS 167 , the level of similarity for the results of two experiments ( $x$ and $y$ ) was lower ( $r$ values, approximately 0.87 ). When replicate experiments were performed with consecutive precultures of strains ORS 112 and ORS 119 grown on TY and TYB(a), on YM and TYB(b), or on YM and YM(c), the levels of similarity were generally lower. Any visible trace of purple color was recorded as a positive result after 5 days of incubation; during the 5 days of incubation positive reactions continued to occur, but no positive reactions occurred after 5 days. However, after 5 days of incubation the purple reaction product precipitated, which precluded the use of an automatic reader; in most cases the results could be read more accurately after the precipitate was resuspended with a sterile wire. We identified five phenotypic clusters that did not correspond to the protein electrophoretic groups; members of protein electrophoretic cluster 1 (Fig. 1) belong to phenotypic clusters I, III, IV, and V, and all members of protein electrophoretic clusters $3,7,8$, and 24 belong to a single phenotypic cluster, cluster II, together with electrophoretic cluster 6 strain ORS 175 and strain ORS 162 that has a unique protein profile.

DNA-rRNA hybridization and 16S rRNA gene sequencing. The results of hybridization of $16 \mathrm{~S}$ or $23 \mathrm{~S}$ rRNA from Bradyrhizobium japonicum LMG $6138^{\mathrm{T}}$ with DNAs from representative strains belonging to gel electrophoretic clusters $1,3,4,6$, $7,8,11$, and 24 are shown in Table 3. DNA-rRNA hybrids obtained with DNAs from members of clusters $1,3,6,7,8$, and 24 had $T_{m(e)}$ values of 77.4 to $78.9^{\circ} \mathrm{C}$, indicating that members of these clusters are very closely related to the type strain of Bradyrhizobium japonicum $\left[T_{m(e)}, 80.2^{\circ} \mathrm{C}\right]$. The representative of cluster 4 and both representatives of cluster 11 had $T_{m(e)}$ values similar to the base level value for rRNA superfamily IV, showing that these organisms are not genomically more closely related to the Bradyrhizobium rRNA cluster than to other members of rRNA superfamily IV.

16S rRNA sequencing was performed with the following six representative strains belonging to different gel electrophoretic clusters: cluster 1 strain LMG $6138^{\mathrm{T}}$ (subcluster B of Moreira et al. [23]), cluster 3 strains BR 3621 and BR 6011 (subclusters $A$ and D, respectively, of Moreira et al. [23]), BR 29 (subcluster C of Moreira et al. [23]), cluster 7 strain ORS 133, and cluster 19 strain BR 4406 (subcluster D of Moreira et al. [23]). A comparative sequence analysis revealed that the cluster 3,6 , 7 , and 19 strains exhibited 99.2 to $99.9 \%$ sequence identity. These organisms exhibited approximately $97.5 \%$ sequence identity with cluster 1 strain LMG $6138^{\mathrm{T}}$ and 95.2 to $96.6 \%$ 
TABLE 2. Results of the Biolog system analysis and differential features for the five Biolog clusters

\begin{tabular}{|c|c|c|c|c|c|}
\hline \multirow[b]{2}{*}{ Carbon source(s) } & \multicolumn{5}{|c|}{ Results obtained with ${ }^{a}$ : } \\
\hline & $\begin{array}{l}\text { Biolog } \\
\text { cluster I }\end{array}$ & $\begin{array}{c}\text { Biolog } \\
\text { cluster II }\end{array}$ & $\begin{array}{c}\text { Biolog } \\
\text { cluster III }\end{array}$ & $\begin{array}{c}\text { Biolog } \\
\text { cluster IV }\end{array}$ & $\begin{array}{c}\text { Biolog } \\
\text { cluster V }\end{array}$ \\
\hline Glycogen & - & $\mathrm{d}$ & - & - & - \\
\hline Xylitol & - & d & - & d & - \\
\hline $\begin{array}{l}\text { Tween } 40 \text {, Tween } 80 \text {, L-arabinose, formic acid, D-gluconic acid, } \\
\alpha \text {-hydroxybutyric acid, sebacic acid, succinic acid }\end{array}$ & + & + & + & + & $\mathrm{d}$ \\
\hline D-Arabitol, D-galactose, cis-aconitic acid & + & + & $\mathrm{d}$ & + & - \\
\hline Adonitol, D-fructose, D-psicose, D-galacturonic acid, itaconic acid, L-fucose & $\mathrm{d}$ & d & - & + & - \\
\hline D-Glucosaminic acid, maltose & $\mathrm{d}$ & $\mathrm{d}$ & - & d & - \\
\hline DL- $\alpha$-Glycerol phosphate & + & - & - & - & - \\
\hline$\alpha$-D-Glucose, D-mannose, D-galactonic acid lactone & + & $\mathrm{d}$ & - & + & - \\
\hline D-Mannitol & + & $\mathrm{d}$ & d & + & - \\
\hline L-Rhamnose & $\mathrm{d}$ & + & - & + & - \\
\hline Monomethyl succinate & + & $\mathrm{d}$ & + & d & + \\
\hline Acetic acid & + & $d$ & $\mathrm{~d}$ & + & $\mathrm{d}$ \\
\hline Citric acid & d & + & + & d & - \\
\hline D-Glucuronic acid, L-proline & $\mathrm{d}$ & - & - & + & - \\
\hline$p$-Hydroxyphenyl acetic acid, D-saccharic acid & $\mathrm{d}$ & + & + & + & $\mathrm{d}$ \\
\hline L-Glutamic acid, glycyl-L-glutamic acid, L-alanine & d & $\mathrm{d}$ & d & + & $\mathrm{d}$ \\
\hline$\alpha$-Ketobutyric acid & + & d & + & + & d \\
\hline$\alpha$-Ketoglutaric acid & d & + & $\mathrm{d}$ & $\mathrm{d}$ & - \\
\hline Malonic acid & d & - & d & $\mathrm{d}$ & $\mathrm{d}$ \\
\hline Propionic acid, L-leucine & $\mathrm{d}$ & + & d & + & $\mathrm{d}$ \\
\hline Quinic acid & + & - & d & + & - \\
\hline$\alpha$-Ketoglutaric acid & $\mathrm{d}$ & + & d & $\mathrm{d}$ & - \\
\hline Bromosuccinic acid & + & + & d & + & $\mathrm{d}$ \\
\hline Glucuronamide & $\mathrm{d}$ & d & - & + & $\mathrm{d}$ \\
\hline Alaninamide & d & d & + & d & d \\
\hline D-Alanine & $\mathrm{d}$ & $\mathrm{d}$ & + & + & $\mathrm{d}$ \\
\hline L-Alanyl-glycine & - & d & $\mathrm{d}$ & $\mathrm{d}$ & - \\
\hline Phenyl ethylamine & - & $\mathrm{d}$ & $\mathrm{d}$ & - & - \\
\hline L-Asparagine, D-sorbitol, D-fructose, L-aspartic acid & $\mathrm{d}$ & d & d & + & - \\
\hline Urocanic acid & d & - & d & + & - \\
\hline$\gamma$-Aminobutyric acid & - & $\mathrm{d}$ & - & + & $\mathrm{d}$ \\
\hline Glycyl-L-aspartic acid & - & - & - & + & - \\
\hline $\begin{array}{l}\text { Methyl pyruvate, } \beta \text {-hydroxybutyric acid, } \gamma \text {-hydroxybutyric acid, DL-lactic acid, } \\
\text { succinamic acid, L-pyroglutamic acid }\end{array}$ & + & + & + & + & + \\
\hline Glycerol & + & + & + & + & - \\
\hline $\begin{array}{l}\alpha \text {-Cyclodextrin, dextrin, } N \text {-acetyl-D-galactosamine, } N \text {-acetyl-D-glucosamine, } \\
\text { cellobiose, i-erythritol, gentiobiose, } m \text {-inositol, } \alpha \text {-D-lactose, lactulose, D- } \\
\text { melibiose, } \beta \text {-methyl-D-glucoside, D-raffinose, sucrose, hydroxy-L-proline, L- } \\
\text { ornithine, L-serine, inosine, uridine, thymidine, putrescine, } 2 \text {-amino ethanol, } \\
\text { 2,3-butanediol, glucose 1-phosphate, glucose 6-phosphate }\end{array}$ & - & - & - & - & - \\
\hline$\alpha$-Ketovaleric acid & $\mathrm{d}$ & d & $\mathrm{d}$ & d & d \\
\hline D-Serine, D-trehalose, turanose, L-threonine & - & - & - & d & - \\
\hline DL-Camitine & $\mathrm{d}$ & - & - & - & - \\
\hline
\end{tabular}

${ }^{a}+$, more than $90 \%$ of the strains are positive; - , more than $90 \%$ of the strains are negative; d, different results (positive or negative).

identity with Rhodopseudomonas palustris, Blastobacter denitrificans, and Afipia strains. Strain LMG $6138^{\mathrm{T}}$ (cluster 1) exhibited 97.6 to $98.5 \%$ sequence identity with Rhodopseudomonas palustris, Blastobacter denitrificans, and Afipia strains. A tree showing the phylogenetic relationships that were calculated by using the Fitch distance matrix method is presented in Fig. 4. The great genotypic variation detected within the few protein electrophoretic clusters included in the rRNA gene sequence analyses indicates that there is considerable genotypic heterogeneity in the Acacia albida-nodulating strains.

\section{DISCUSSION}

Many new slowly growing isolates have been examined by determining the SDS-PAGE patterns of their cellular proteins (23). Most of these strains clustered with Bradyrhizobium reference strains, including the type strain of Bradyrhizobium japonicum, in a large cluster equivalent to cluster 12 (with subclusters 12A through 12E) of Moreira et al. (23). We included many new strains, and only some members of the former Bradyrhizobium cluster (23) were recovered in clusters 1 to 9; representatives of Bradyrhizobium subclusters $12 \mathrm{C}$ and 12D described previously were members of our clusters 12 and 19. A small cluster (number 13 of Moreira et al. [23]), which was described as the closest neighbor of the Bradyrhizobium cluster, constitutes our cluster 5 . In this context it is worth noting that we previously identified strains LMG $6134^{\mathrm{T}}$, LMG 6135 (Bradyrhizobium elkanii), and LMG 6136 (Bradyrhizobium japonicum) as members of a single subcluster, subcluster 12E (23); however, strains LMG $6134^{\mathrm{T}}$ and LMG 6135 were found to be genotypically distinct from LMG 6136 (DNA homology groups II and I, respectively $[11,36])$. In this study strains LMG 6135 and LMG $6134^{\mathrm{T}}$ were indeed found to be members of a separate SDS-PAGE cluster, cluster 6 , while 


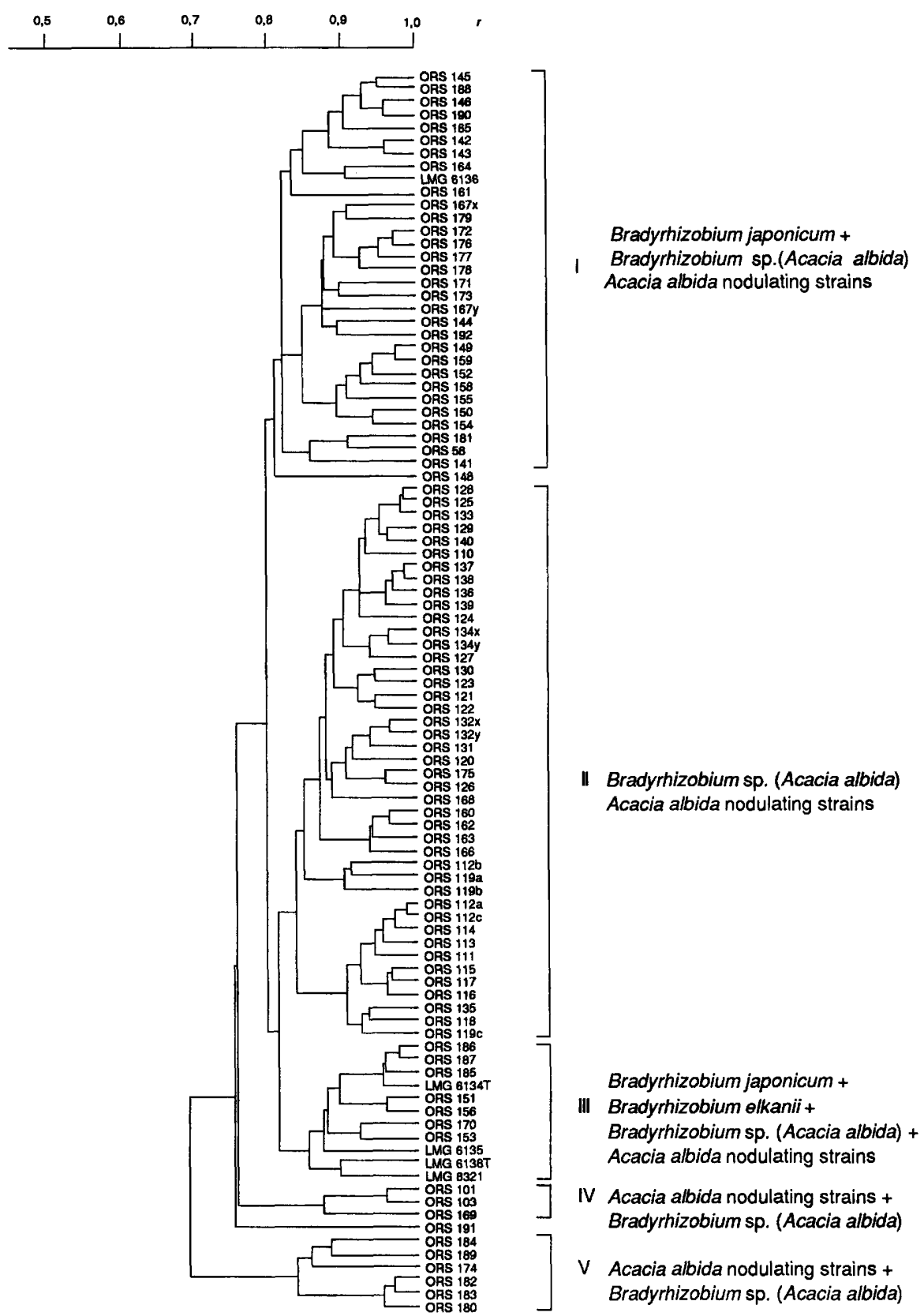

FIG. 3. Biolog results presented as a dendrogram based on $r$ values, as calculated by the unweighted group method using average linkage.

LMG 6136 and LMG $6138^{\mathrm{T}}$ (also a member of DNA homology group I) belong in SDS-PAGE clusters 3 and 1, respectively. These findings demonstrate that protein electrophoretic cluster delineation was improved by the addition of new strains and/or the use of new normalization principles. The fact that clusters of potential Bradyrhizobium species can be found among clusters containing only Rhizobium species demonstrates that SDS-PAGE cannot discriminate at the genus level but is only useful for grouping large numbers of strains into clusters having potential species status. Genotypic data are necessary to confirm these findings. When the protein patterns of slowly growing Bradyrhizobium strains are examined, care has to be taken with interpretation of the resulting cluster analysis data. Probably because of long incubation times, the bands in the protein patterns tend to be less distinct and less sharp than the bands in patterns derived from fast-growing strains (compare Bradyrhizobium and Rhizobium patterns in Fig. 2). Similarly, calculations tend to depend more on the matching of zones composed of rather fuzzy protein bands than on exact matching of well-defined, sharp protein peaks. Numerical analyses in which $r$ values are used for this type of pattern therefore are influenced more by the specific selection of strains, resulting in a relatively large number of loosely associated strains and in a number of clusters that changes depending on the total number of patterns included in the analysis. More distinct patterns can be obtained by removing common "background" absorbance data, as described by Vauterin and Vauterin (31). Additional investigations are being 
TABLE 3. $T_{m(e)}$ values of hybrids between DNAs of Acacia albidanodulating strains and labeled rRNA from Bradyrhizobium japonicum LMG $6138^{\mathrm{T}}$ (= NZP 5549 ${ }^{\mathrm{T}}$ )

\begin{tabular}{|c|c|c|c|}
\hline \multicolumn{2}{|c|}{ Organism used for DNA isolation } & \multirow{2}{*}{$\begin{array}{l}\text { SDS-PAGE } \\
\text { group }\end{array}$} & \multirow{2}{*}{$T_{m(e)}\left({ }^{\circ} \mathrm{C}\right)$} \\
\hline Taxon & Strain & & \\
\hline $\begin{array}{l}\text { Bradyrhizobium } \\
\text { japonicum }\end{array}$ & LMG $6138^{\mathrm{T}}$ & 1 & 80.2 \\
\hline $\begin{array}{l}\text { Bradyrhizobium sp. } \\
\text { (Acacia albida) }\end{array}$ & ORS 103 & 1 & 78.9 \\
\hline $\begin{array}{l}\text { Bradyrhizobium sp. } \\
\text { (Acacia albida) }\end{array}$ & ORS 135 & 3 & 78.6 \\
\hline $\begin{array}{l}\text { Acacia albida- } \\
\text { nodulating strain }\end{array}$ & ORS 174 & 4 & 69.5 \\
\hline $\begin{array}{l}\text { Bradyrhizobium sp. } \\
\text { (Acacia albida) }\end{array}$ & ORS 170 & 6 & 78.7 \\
\hline $\begin{array}{l}\text { Bradyrhizobium sp. } \\
\text { (Acacia albida) }\end{array}$ & ORS 175 & 6 & 79.7 \\
\hline $\begin{array}{l}\text { Bradyrhizobium sp. } \\
\text { (Acacia albida) }\end{array}$ & ORS 133 & 7 & 77.4 \\
\hline $\begin{array}{l}\text { Bradyrhizobium sp. } \\
\text { (Acacia albida) }\end{array}$ & ORS 134 & 8 & 77.7 \\
\hline $\begin{array}{l}\text { Acacia albida- } \\
\text { nodulating strain }\end{array}$ & ORS 182 & 11 & 66.7 \\
\hline $\begin{array}{l}\text { Acacia albida- } \\
\text { nodulating strain }\end{array}$ & ORS 183 & 11 & 66.8 \\
\hline $\begin{array}{l}\text { Bradyrhizobium sp. } \\
\text { (Acacia albida) }\end{array}$ & ORS 114 & 24 & 78.0 \\
\hline
\end{tabular}

performed at this time to determine the influence of this type of data modification on Bradyrhizonium protein patterns. Until more information is available, care should be taken with delineation and naming of protein electrophoretic clusters or subclusters without additional confirmation by genotypic tests.

No clear relationship between the depth of isolation at a particular site and protein electrophoretic group was found. On the other hand, the geographic origins of the strains did exhibit some correlation with the protein electrophoretic grouping results; all members of clusters 7 and 8 originated from Louga, and within cluster 1 most strains isolated from Diokoul, Djinaki, and Kabrousse soils grouped together. Strains obtained from various Sudano-Guinean and Sahelian surface soils were electrophoretically more heterogeneous, indicating that there is a horizontal distribution of Acacia albida-nodulating strains.

Because classical phenotypic studies are very labor intensive and sometimes difficult to interpret when slowly growing bacteria are used, commercial systems were used to characterize the Acacia albida-nodulating strains phenotypically. Auxanography with API 50 systems was not possible because of the slow growth of bradyrhizobia. The Biolog system gave a better response after we changed the incubation times of the precultures and the reaction mixtures. No clear correlation with the SDS-PAGE groups was found because only five phenotypic clusters (clusters I to $\mathrm{V}$ ) were obtained for the strains belonging to 10 electrophoretic clusters (clusters 1, 3, 4, 6, 7, 8, 9, 11, 21 , and 24) and members of SDS-PAGE cluster 1 belonged to at least three phenotypic clusters. Genotypic techniques are needed to evaluate the clusters obtained by the Biolog system and SDS-PAGE. The differentiating power of the Biolog system is also difficult to judge because the results in Table 2 demonstrate that for most of the substrates a $\mathrm{d}$ response was obtained; consequently, this system provides few clear-cut differentiating features. To discriminate cluster I from clusters II, III, IV, and V, oxidation of DL- $\alpha$-glycerol phosphate proved to be a useful characteristic. In addition, oxidation of glycyl-L- aspartic acid and glycerol differentiated clusters IV and V. Clusters II and III could not be differentiated from each other.

In order to determine whether the Acacia albida-nodulating strains are related to the genus Bradyrhizobium, representative strains of the protein electrophoretic clusters were characterized genotypically. DNA-rRNA hybridizations revealed that representatives of clusters $1,3,6,7,8$, and 24 are very closely related to Bradyrhizobium japonicum LMG $6138^{\mathrm{T}}\left[T_{m(e)}\right.$ values, more than $77.4^{\circ} \mathrm{Cl}$ and belong to the BradyrhizobiumRhodopseudomonas-Blastobacter denitrificans rRNA complex $(10,12)$ in the alpha subclass of the Proteobacteria (29). Both representatives of cluster 11 had $T_{m(e)}$ values similar to the base value for rRNA superfamily IV, indicating that these organisms are not more closely related to members of the complex mentioned above than to other members of rRNA superfamily IV. The protein profile of cluster 4 representative strain ORS 174 was in the middle of the Bradyrhizobium cluster 1 to 9 profiles. However, this strain was found to be only remotely related to the genus Bradyrhizobium on the basis of DNA-rRNA hybridization data. Additional studies are necessary to clarify the position of the strains belonging to protein electrophoretic cluster 4 and also the positions of strains belonging to protein electrophoretic clusters 21, 24, and 25.

It was evident from the DNA-rRNA hybridization data that most of the isolates that nodulate Acacia albida and the strains belonging to subclusters A through D of Moreira et al. (23) are phylogenetically related to the genus Bradyrhizobium. However, a comparative 16S rRNA gene sequence analysis demonstrated that representatives of clusters 6 (BR 29), 7 (ORS 133), 3 (BR 6011 and BR 3621), and 19 (BR 4406) are closely related to each other and form a separate line of descent (Fig. 4) that is distinct from Bradyrhizobium japonicum LMG $6138^{\mathrm{T}}$ (representing cluster 1). More studies are needed to determine whether all members of this cluster (mostly Acacia albidanodulating strains) form a homogeneous genotypic group and belong to the same line of descent as Bradyrhizobium japonicum, as expected from the results of the SDS-PAGE analysis. The generic placement of the line (containing representatives of PAGE clusters 3, 6, 7, and 19), however, is problematic. It is evident from the branching pattern of the tree that the strains belonging to this line are the most peripheral members of the Afipia-Bradyrhizobium-Rhodopseudomonas clade. Strain BR 29 is a member of the same PAGE group (cluster 6) as the type strain of the recently described organism Bradyrhizobium elkanii. Because of tree topology considerations, inclusion of the latter taxon in the same genus as Bradyrhizobium japonicum would mean that all members of this rRNA group (i.e., Afipia strains, Blastobacter denitrificans, Rhodopseudomonas palustris, Nitrobacter strains) would have to be placed in a single genus. The analysis of partial rhizobial rRNA sequences described by Young et al. (36) and Segovia et al. (28) (in which a 260- or 318-base fragment was used) revealed similar heterogeneity in Bradyrhizobium isolates, confirming this problem. The results of analyses of partial 16S rRNA sequences suggest that a representative of DNA homology group Ia belongs in another separate lineage together with Bradyrhizobium sp. strain BTAi1 (36). These strains were not included in this study, and it is evident that more studies are needed to determine the complex internal structure of the genus Bradyrhizobium. On this taxonomic level, SDS-PAGE of whole-cell proteins is helpful for grouping highly related strains, but chromosomal DNA-DNA pairing and additional ribosomal DNA sequencing studies clearly are necessary to determine the taxonomic status of the different clusters. 


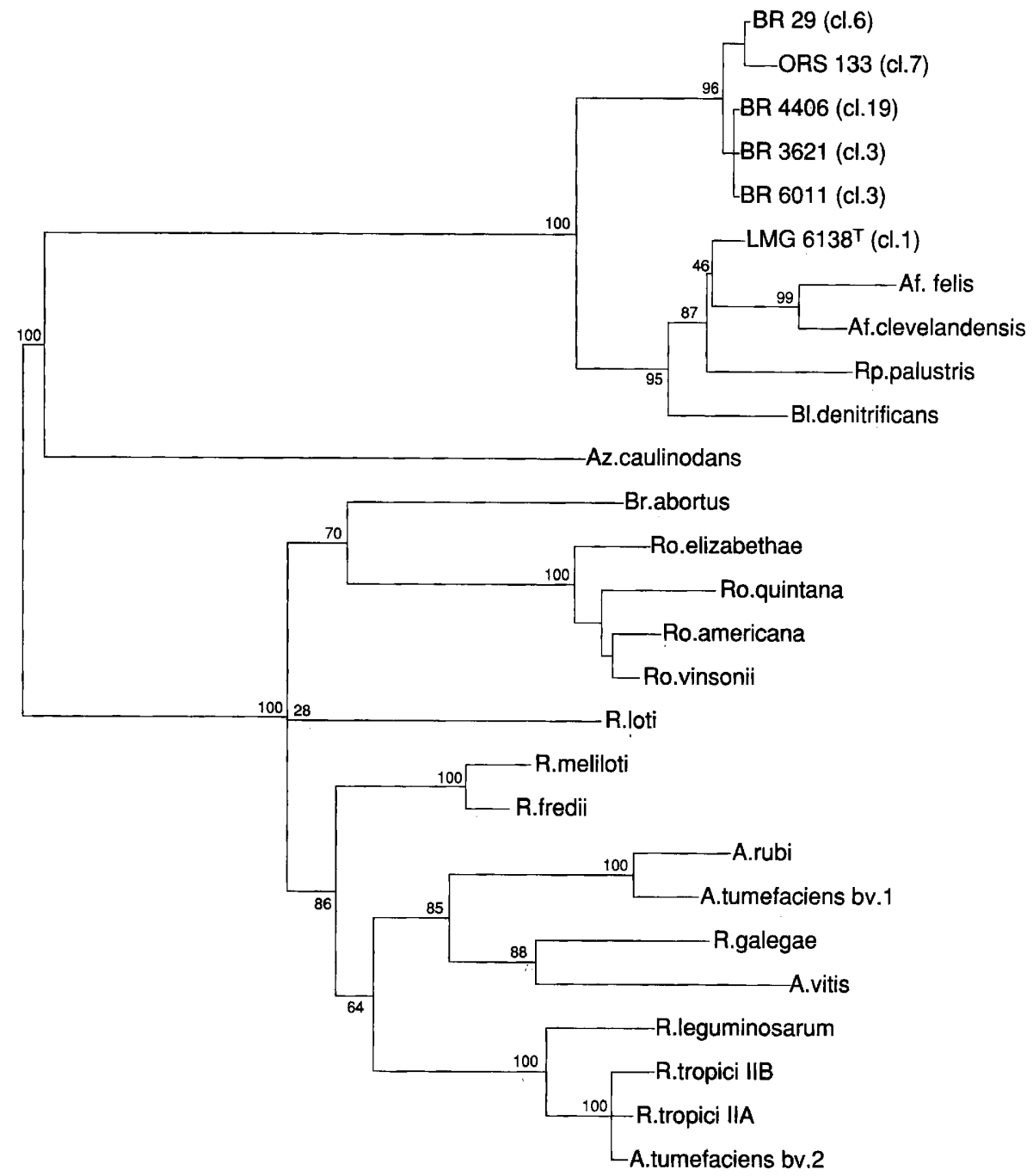

FIG. 4. Unrooted dendrogram obtained by Fitch analysis, showing the relationships of representative Bradyrhizobium strains and related taxa belonging to the alpha-2 subgroup of the Proteobacteria. Bootstrap probability values are indicated at the branching points. Abbreviations: A., Agrobacterium; Af., Afipia; Az., Azorhizobium; Bl., Blastobacter; Br., Brucella; R., Rhizobium; Ro., Rochalimaea; Rp., Rhodopseudomonas; cl., PAGE cluster.

\section{ACKNOWLEDGMENTS}

M.G. and K.K. are indebted to the National Fund for Medical Scientific Research, Belgium, for research and personnel grants. Part of this work was carried out within the framework of contract BIOT-CT91-0263 between K.K. and the Commission of the European Communities. Part of this work was supported by a sectoral grant (to A.W.) from the BRIDGE program and by grant TS2-0169 from the Commission of the European Communities.

We also thank the ORSTOM-MAA Department.

\section{REFERENCES}

1. Brosius, J., M. L. Palmer, P. J. Kennedy, and H. F. Noller. 1978 Complete nucleotide sequence of a $16 \mathrm{~S}$ ribosomal RNA gene from Escherichia coli. Proc. Natl. Acad. Sci. USA 75:4801-4805.

2. Chen, W. X., G. S. Li, Y. L. Qi, E. T. Wang, H. L. Yuan, and J. L. Li. 1991. Rhizobium huakuii sp. nov. isolated from the root nodules of Astragalus sinicus. Int. J. Syst. Bacteriol. 41:275-280.

3. Chen, W. X., G. H. Yan, and J. L. Li. 1988. Numerical taxonomy study of fast-growing soybean rhizobia and a proposal that Rhizobium fredii be assigned to Sinorhizobium gen. nov. Int. J. Syst. Bacteriol. 38:392-397.

4. de Lajudie, P., A. Willems, B. Pot, D. Dewettinck, G. Maestrojuan,
M. Neyra, M. D. Collins, B. Dreyfus, K. Kersters, and M. Gillis. Submitted for publication.

5. Devereux, J., P. Haeberli, and D. Smithies. 1984. A comprehensive set of sequence programs for the VAX. Nucleic Acids Res. 12:387-395.

6. Dreyfus, B., J. L. Garcia, and M. Gillis. 1988. Characterization of Azorhizobium caulinodans gen. nov., sp. nov., a stem-nodulating nitrogen-fixing bacterium isolated from Sesbania rostrata. Int. J. Syst. Bacteriol. 38:89-98.

7. Dupuy, N. C., and B. L. Dreyfus. 1992. Bradyrhizobium populations occur in deep soil under the leguminous tree Acacia albida. Appl. Environ. Microbiol. 58:2415-2419.

8. Felsenstein, J. 1989. PHYLIP-phylogeny inference package (version 3.2). Cladistics 5:164-166.

9. Graham, P. H., M. J. Sadowsky, H. H. Keyser, Y. M. Barnet, R. S. Bradley, J. E. Cooper, D. J. De Ley, B. D. W. Jarvis, E. B. Roslycky, B. W. Strijdom, and J. P. W. Young. 1991. Proposed minimal standards for the description of new genera and species of rootand stem-nodulating bacteria. Int. J. Syst. Bacteriol. 41:582-587.

10. Green, P. N., and M. Gillis. 1989. Classification of Pseudomonas aminovorans and some related methylated amine utilizing bacteria. J. Gen. Microbiol. 135:2071-2076. 
11. Hollis, T. A., W. E. Kloos, and G. H. Elkan. 1981. DNA:DNA hybridization studies of Rhizobium japonicum and related Rhizobiaceae. J. Gen. Microbiol. 123:215-222.

12. Irgens, R. L., K. Kersters, P. Segers, M. Gillis, and J. T. Staley. 1991. Aquabacter spiritensis gen. nov., sp. nov., an aerobic, gasvacuolate aquatic bacterium. Arch. Microbiol. 155:137-142.

13. Jarvis, B. D. W., H. L. Downer, and J. P. W. Young. 1992. Phylogeny of fast-growing soybean-nodulating rhizobia supports synonymy of Sinorhizobium and Rhizobium and assignment to Rhizobium fredii. Int. J. Syst. Bacteriol. 42:93-96.

14. Jarvis, B. D. W., M. Gillis, and J. De Ley. 1986. Intra- and intergeneric similarities between the ribosomal ribonucleic acid cistrons of Rhizobium and Bradyrhizobium species and some related bacteria. Int. J. Syst. Bacteriol. 36:129-138.

15. Jordan, D. C. 1982 . Transfer of Rhizobium japonicum Buchanan 1980 to Bradyrhizobium gen. nov., a genus of slow-growing, root nodule bacteria from leguminous plants. Int. J. Syst. Bacteriol. 32:136-139.

16. Jordan, D. C. 1984. Rhizobiaceae Conn $1938,321^{\mathrm{AL}}$, p. 234-256. In N. R. Krieg and J. G. Holt (ed.), Bergey's manual of systematic bacteriology, vol. 1. The Williams \& Wilkins Co., Baltimore.

17. Kiredjian, M., B. Holmes, K. Kersters, J. Guilvout, and J. De Ley. 1986. Alcaligenes piechaudii, a new species from human clinical specimens and the environment. Int. J. Syst. Bacteriol. 36:282-287.

18. Kuykendall, L. D., M. A. Roy, J. J. O'Neill, and T. E. Devine. 1988 Fatty acids, antibiotic resistance, and deoxyribonucleic acid homology groups of Bradyrhizobium japonicum. Int. Syst. Bacteriol. 38:358-361.

19. Kuykendall, L. D., B. Saxena, T. E. Devine, and S. E. Udell. 1992. Genetic diversity in Bradyrhizobium japonicum (Jordan, 1982) and a proposal for Bradyrhizobium elkanii sp. nov. Can. J. Microbiol. 38:501-505.

20. Laemmli, U. K. 1970. Cleavage of structural proteins during the assembly of the head of bacteriophage T4. Nature (London) 227:680-685.

21. Lindström, K. 1989. Rhizobium galegae, a new species of legume root nodule bacteria. Int. J. Syst. Bacteriol. 39:365-367.

22. Martinez-Romero, E., L. Segovia, F. M. Mercante, A. A. Franco, P. Graham, and M. A. Pardo. 1991. Rhizobium tropici, a novel species nodulating Phaseolus vulgaris L. beans and Leucaena sp. trees. Int. J. Syst. Bacteriol. 41:417-426.

23. Moreira, F. M. S., M. Gillis, B. Pot, K. Kersters, and A. A. Franco. 1993. Characterization of rhizobia isolated from different divergence groups of tropical Leguminosae by comparative polyacrylamide gel electrophoresis of their total proteins. Syst. Appl. Microbiol. 16:135-146.

24. Pot, B., M. Gillis, B. Hoste, A. Van De Velde, F. Bekaert, K.
Kersters, and J. De Ley. 1989. Intra- and intergeneric relationships of the genus Oceanospirillum. Int. J. Syst. Bacteriol. 39:23-34.

25. Pot, B., P. Vandamme, and K. Kersters. 1993. Analysis of electrophoretic whole organism protein fingerprints, p. 493-521. In M. Goodfellow and A. G. O'Donnel (ed.), Chemical methods in prokaryotic systematics. John Wiley \& Sons, Chichester, England.

26. Rinaudo, G., S. Orenga, M. P. Fernandez, H. Meugnier, and R. Bardin. 1991. DNA homologies among members of the genus Azorhizobium and other stem- and root-nodulating bacteria isolated from the tropical legume Sesbania rostrata. Int. J. Syst. Bacteriol. 41:114-120.

27. Scholla, M. H., and G. H. Elkan. 1984. Rhizobium fredii sp. nov., a fast-growing species that effectively nodulates soybeans. Int. J. Syst. Bacteriol. 34:484-486.

28. Segovia, L., J. P. W. Young, and E. Martinez-Romero. 1993. Reclassification of American Rhizobium leguminosarum biovar phaseoli type I strains as Rhizobium etli sp. nov. Int. J. Syst. Bacteriol. 43:374-377.

29. Stackebrandt, E., R. G. E. Murray, and H. G. Trüper. 1988. Proteobacteria classis nov., a name for the phylogenetic taxon that includes the "purple bacteria and their relatives." Int. J. Syst. Bacteriol. 38:321-325.

30. Turk, D., and H. H. Keyser. 1992. Rhizobia that nodulate tree legumes: specificity of the host for nodulation and effectiveness. Can. J. Microbiol. 38:451-460.

31. Vauterin, L., and P. Vauterin. 1992. Computer-aided objective comparison of electrophoresis patterns for grouping and identification of microorganisms. Eur. Microbiol. 1:37-41.

32. Vauterin, L., and P. Vauterin. Unpublished data.

33. Vincent, J. M. 1970 . A manual for practical study of root-nodule bacteria. International Biological Programme Handbook no. 15, p. 164. Blackwell Scientific Publications, Ltd., Oxford.

34. Willems, A., and M. D. Collins. 1992. Evidence for a close genealogical relationship between Afipia, the causal organism of cat scratch disease, Bradyrhizobium japonicum and Blastobacter denitrificans. FEMS Microbiol. Lett. 96:241-246.

35. Willems, A., and M. D. Collins. 1993. Phylogenetic analysis of rhizobia and agrobacteria based on $16 \mathrm{~S}$ rRNA sequences. Int. J. Syst. Bacteriol. 43:305-313.

36. Young, J. P. W., H. L. Downer, and B. D. Eardly. 1991. Phylogeny of the phototropic Rhizobium strain BTAi1 by polymerase chain reaction-based sequencing of a $16 \mathrm{~S}$ rRNA gene segment. J. Bacteriol. 173:2271-2277.

37. Zhang, X., R. Harper, M. Karsisto, and K. Lindström. 1991. Diversity of Rhizobium bacteria isolated from the root nodules of leguminous trees. Int. J. Syst. Bacteriol. 41:104-113. 